\title{
The Principles of Changing Land Use Classification under Special Provisions in the Areas of Poland where Landslide Movements and the Risk of Landslide Movements Occur
}

\section{Areas of Poland where Landslides Occur Posing a Threat to Buildings. A Landslide as a Natural Disaster}

In Poland, the Carpathians and the Sub-Carpathian region where land mass movements and the risk of them occur are considered landslide areas. As it follows from the project entitled Landslide Counteracting System (system osłony przeciwosuwiskowej-SOPO), the landslide rate expressing the size of an area in which landslides occur and which is threatened by them compared to the total land surface area is high here and assessed at 30-40\% [3].

In the face of landslide events caused by intense precipitation which took place in May and June 2010 in Poland, a large number of landslides was recorded andby extension, a lot of damage to residential buildings. Losses, according to the data of the Ministry of Interior and Administration, were recorded in four voivodeships: Małopolskie, Podkarpackie, Śląskie and Świętokrzyskie. In total, they affected 107 communes and 1,639 buildings, in the case of Świętokrzyskie Voivodeship the losses were scarce (1 building). Landslides posing a threat to buildings occurred in 57 communes in Małopolskie Voivodeship, 34 communes in Podkarpackie Voivodeship and 16 communes in Śląskie Voivodeship (in the area of two voivodeships: Małopolskie and Śląskie 1,345 landslides occurred). In Małopolskie Voivodeship the majority of landslides occurred in Wadowicki Poviat (Lanckorona commune), Limanowski Poviat (Laskowa and Limanowa commune) and Nowosądecki Poviat (Łososina Dolna and Gródek nad Dunajcem communes) as well as Tarnowski Poviat (Pleśna and Tuchów communes). In Podkarpackie Voivodeship the areas of the following poviats are the most threatened: Jasielski, Strzyżowski, Dębicki, Sędziszowsko-ropczycki and Rzeszowski [3].

\footnotetext{
* (Kielce University of Technology, Poland
} 
Due to the fact of defining a landslide as an event related to forces of nature [7], thus thinking of it in terms of a natural disaster, it has become necessary to ensure an extraordinary mode of help to the injured. The disastrous nature of landslides from the first half of 2010 revealed gaps in special provisions enabling fast, short-term action in the areas affected by the natural disaster. Legislative changes were to concern facilitating and speeding up the reconstruction of destroyed and damaged structures. It was considered necessary to establish principles and conditions on which the reconstruction of buildings in the former place would ensure their users' safety as well as to create the possibility of reconstructing destroyed buildings in another safe place.

\section{Spatial Planning in a Commune in Areas Threatened by Landslides}

The main instrument of pursuing spatial policy of a commune is, on the statutory assumption, the local spatial development plan which comprehensively specifies the principles of land development of an area within the scope of application, therefore, it determines land use classification. In the case of areas to which the local plan does not apply, the principles of land development and its potential limitations are specified in the decision on land development conditions or in the decision on the location of a public purpose investment.

On 16 August 2010 the Act of 6 August 2010 on amending the Act on special principles of the reconstruction, renovation and demolition of structures destroyed or damaged as a result of the destructive influence of the element as well as some other acts [9] came into effect, which caused, among other things, amendments in the provisions of the Spatial Planning and Land Development Act [8] with respect to areas threatened by land mass movements. Such areas should be in particular specified in the study of conditions and directions of land development of a commune as well as in the local spatial development plan. Figure 1 presents a fragment of the graphic part of the local spatial development plan in which areas threatened by landslide movements are included.

It is worth mentioning at this point, after Bieda, Hanus, Hycner [1] and Kwartnik-Pruc, Szafarczyk [2], that it is not required in any provision of law that the decision on land development conditions is, in its scope, in conformity with the provisions of the study of conditions and directions of land development of a commune, which is obvious inconsistency in comparison to the local plan for which the provisions of the study are binding. This fact is of particularly great significance when there are areas threatened by landslides in a commune and their specificity is not taken into consideration in land development. In areas threatened by such events either the limitation or, in some cases, the complete prohibition of land development is important. It will prevent excessive land load, slope cutting and therefore, it may minimise the probability of future landslide movements as well as, by extension, damage to buildigns and infrastructure. 

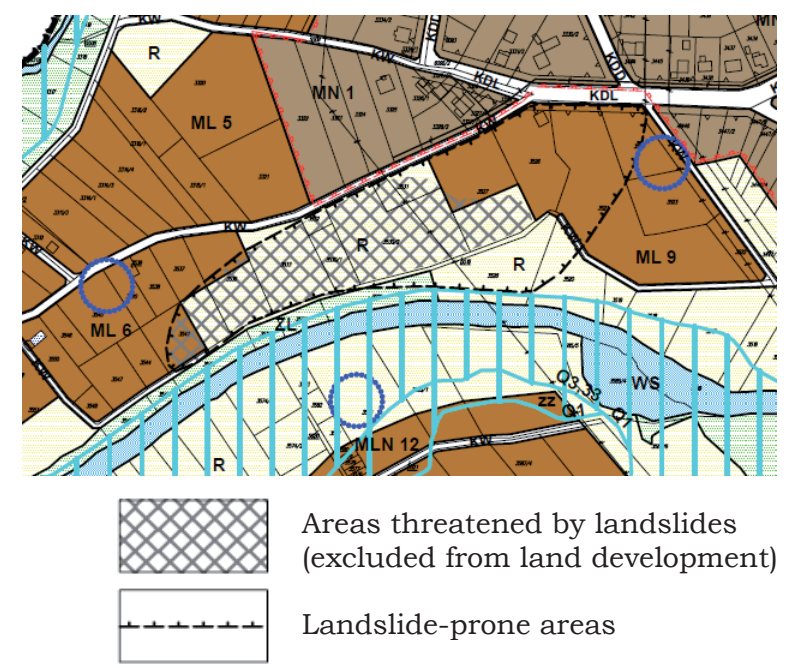

Areas threatened by landslides (excluded from land development)

Landslide-prone areas

Fig. 1. A fragment of the graphic part of the local spatial development plan of the town of Jordanow including areas threatened by landslides

Source: www.jordanow.pl

There are, of course, areas where land mass movements occur in the places where they have not occurred before and at the stage of spatial planning in a commune there was no information about their risk. As it follows from forecasts connected with climatic changes on the Earth, the probability of abnormal weather conditions, eg. intense sudden downpours, is increasing, which may be one of the factore inducing landslide events.

Certainly thanks to the comprehensive programme entitiled Landslide Counteracting System (system osłony przeciwosuwiskowej SOPO) the number of places where disastrous landslides will suddenly occur will be decreasing [4]. The main objective, that is supporting administrative bodies with reliable data on geohazards in full and effective landslide risk management is already being carried out, which can be seen on the example of newly created planning acts and including landslide hazards in them.

\section{The Act on Special Principles of the Reconstruction, Renovation and Demolition of Structures Destroyed or Damaged} as a Result of the Destructive Influence of the Element
as the Basis for the Change in Land Use Classification

The Act of 11 August 2001 [6] stipulates special principles of the reconstruction, renovation and demolition of structures destroyed or damaged as a result of the destructive influence of the element, among other things, landslides. It defines the reconstruction of structures as the act of their rebuilding in the same place with the 
use of the same or other materials. The amendment of this Act came into force on 16 August 2010 [9] and it provides for, among other things, a special procedure for the reconstruction of damaged structures. In particular, these changes are aimed at:

- enabling the reconstruction of destroyed structures in other place than the previous one on account of occurring hazards,

- creating the possibility to relocate the inhabitants of areas threatened by another landslide through preparing and enacting local reconstruction plans,

- conferring powers on commune authorities to enact acts of local law in order to ensure the safety of people and property,

- the introduction of principles applying to the reconstruction of structures in their former place in order to ensure the safety of their usage.

As can be seen, the definition of reconstruction itself understood [9] also as rebuilding a structure of the same or other dimensions in other place, determined in the local reconstruction plan has changed.

Due to the thematic scope of this publication, the provisions of the Act concerning post-landslide areas development through the change of previous land use classification including the implementation of local reconstruction plans were focused on. As it follows from the provisions of the Act (Art. 2) [9], the Prime Minister, on the basis of the data received from competent voivodes, taking into account the kind of a natural disaster and its effects, for the period no longer than 24 months, by way of regulation, determines communes and places to which the special principles of the reconstruction, renovation and demolition of structures are applied and the special principles of land development as well as the priniciples and mode of purchasing real properties in connection with landslides. Placing a commune in such a register is a necessary condition for applying procedures under special provisions in its area due to the disastrous nature of damage caused by various elements eg. intense precipitation, a hailstorm, a whirlwind etc. (including landslides). In the case of landslide-affected areas the Act provides for the possibility of mapping out three types of areas and regulating the principles of land use classification within them in the form of acts of local law. These are:

- areas where destruction or damage to structures resulted from a landslide and where the reconstruction of the structures takes place on special conditions (the permanent stabilisation of the land with the use of appropriate methods and obtaining a building permit under the provisions of the Act is a condition);

- an area where the construction of new buildings, the reconstruction and outward extension, alteration and upward extension of existing buildings are prohibited in order to ensure the safety of people and property;

- an area where the local plan of building structures reconstruction is in force (the local reconstruction plan); its enactment by the commune council gives the possibility of relocating the inhabitants of landslide areas to other regions, therefore, it enables the reconstruction of their buildings in other place and of different dimensions. 
Placing the first two types of areas in the register kept by the staroste pursuant to the Act of 27 April 2001 Environmental Protection Law (Journal of Laws of 2001, No. 62, item 627) [5], upon the request of the Executive of a commune (a commune head, a mayor, a city mayor) is the condition for establishing them. On the other hand, in order to enable the injured to reconstruct in areas other than the ones specified in the first two points, the commune council may enact the local plan of building structures reconstruction. Those whose real properties were encompassed by the acts of local law limiting the manner of reconstruction in the former place or excluding the construction of new buildings are entitled to purchasing real properties included in the reconstruction plan. The local reconstruction plan is, to some extent, a simplified procedure of the local spatial development plan. It was the legislator's intent, however, that it should not be a tool of pursuing the spatial policy of a commune but only the means of helping those who were injured as a result of a natural disaster.

The local reconstruction plan specifies the outer borders of lands allotted to the reconstruction of structures destroyed or damaged as a result of a landslide and determines:

- land use classification,

- the principles and conditions of separating new construction plots,

- the manner and conditions of land development,

- the building alignments, the dimensions of structures and plot ratios,

- the principles of alteration or construction of linear structures which belong to a commune's own tasks,

- the manner of water and electricity supply as well as the manner of sewage disposal,

- the principles of environment, nature and cultural landscape protection.

In the case of areas under building prohibition and included in the local reconstruction plan, enacting acts of local law by the commune council is connected with the change of the former land use classification or its limitation. It involves financial effects for the budget of a commune (paying damages, the purchase of real property or its part within the statutory period, potential contractual interest, roads and infrastructure construction in areas determined in the local reconstruction plan, compensation for real property expropriation).

\section{The Description of the Analyses Carried out, Determining the Scope of Research}

The main purpose of this publication is to examine if and to what extent communes from the areas of Poland affected by landslide-related disasters take advantage of the possibillity given by the Act on special principles of the reconstruction, renovation and demolition of structures destroyed or damaged as a result of the destructive influence of the element [6]. The research concerned communes' activities 
with respect to the change of land use classification under special provisions through enacting acts of local law. The possibility of taking measures in this respect is a result of the amendments to the Act [6] after disastrous landslide phenomena which took place in Poland in the first half of 2010. Therefore, the ananlysis includes the period from 16 August 2010 - the moment of the Act coming into force [9] to the present moment (November 2014).

The areas of Poland where land mass movements and their risk occur were adopted as the field of research. These are, first of all, the Carpathians and the Sub-Carpathian region. The areas of four voivodeships were analysed: Małopolskie, Podkarpackie, Śląskie and Świętokrzyskie. In Świętokrzyskie Voivodeship, as the situation from the first half of 2010 showed, landslide movements are occasional.

In order to examine how many communes from the chosen research area were entitled to apply the provisions of the said Act, all the resolutions of the Prime Minister which were in force in the analysed period were found. At that time eight executive regulations to the Act [9] concerning communes from the four examined voivodeships were passed. These communes suffered damage as a result of the destructive influence of the elements, in particular landslides. Regulations referring to communes for which landslide events were not mentioned in the title of the communes register were excluded from further analyses (communes referred to in these regulations suffered damage as a result of the influence of other elements, eg. floods, hurricane-force winds, fires etc.). The results are presented in Table 1.

Table 1. The number of communes named in executive regulations to the Act [9] in 2010-2014 from the adopted research area

\begin{tabular}{|c|c|c|c|c|c|c|}
\hline \multirow{2}{*}{ No. } & \multirow{2}{*}{ Regulation } & \multirow{2}{*}{$\begin{array}{l}\text { Binding } \\
\text { since }\end{array}$} & \multicolumn{4}{|c|}{$\begin{array}{l}\text { The number of communes marked out in the registers } \\
\text { to the regulations }\end{array}$} \\
\hline & & & $\begin{array}{l}\text { Małopolskie } \\
\text { Voivodeship }\end{array}$ & $\begin{array}{l}\text { Podkarpackie } \\
\text { Voivodeship }\end{array}$ & \begin{tabular}{c|} 
Śląskie \\
Voivodeship
\end{tabular} & $\begin{array}{l}\text { Świętokrzyskie } \\
\text { Voivodeship }\end{array}$ \\
\hline 1 & $\begin{array}{l}\text { Dz.U. [Journal of } \\
\text { Laws] 2010.212.1389 }\end{array}$ & 4.11 .2010 & 1 & 0 & 41 & 0 \\
\hline 2 & $\begin{array}{l}\text { Dz.U.2011.514+ as } \\
\text { amended 2011.246.1468 }\end{array}$ & 4.01.2011, & 108 & 86 & 20 & 1 \\
\hline 3 & Dz.U.2012.907 & 8.08 .2012 & 1 & 0 & 13 & 3 \\
\hline 4 & Dz.U.2012.1119 & 6.10 .2012 & 2 & 0 & 4 & 21 \\
\hline 5 & Dz.U.2012.1439 & 18.12.2012 & 0 & 0 & 3 & 0 \\
\hline 6 & Dz.U.2013.570 & 14.05.2013 & 0 & 0 & 6 & 12 \\
\hline 7 & Dz.U.2013.1029 & 6.09 .2013 & 127 & 27 & 70 & 21 \\
\hline 8 & Dz.U.2014.1107 & 15.08.2014 & 138 & 10 & 29 & 31 \\
\hline \multicolumn{3}{|c|}{$\begin{array}{l}\text { The total number of communes marked } \\
\text { out in binding regulations }\end{array}$} & 247 & 96 & 91 & 32 \\
\hline
\end{tabular}

Highlighted in grey - regulations not concerning landslide disasters. 
In the regulations passed before the Act coming into effect [9] a large number of communes were placed in the registers, the type of the element was not included in the title of the register. Moreover, in the registers to the subsequent regulations the same communes were frequently referred to several times. Therefore, it is difficult to analyse the provisions of the regulations from before 16 August 2010 (the Act amending the Act coming into force [6]) specifically with respect to landslide events. In regulations passed later certain organisation of the registers can be seen. Legislative acts presented in Table 1 from ordinal number 3 to 7 do not concern disasters caused by landslides. They include communes injured as a result of the influence of other elements, eg. floods, hurricane-force winds, hail (in the title of the register landslide phenomena do no appear). On the other hand, in the regulation of 4 January 2011 (Fig. 2), for instance, in a separate register there are communes injured as a result of a landslide.

\footnotetext{
Regulation of the Prime Minister on communes in which special principles of the reconstruction, renovation and demolition of structures destroyed or damaged as a result of the destructive influence of the element and special principles of land development as well as principles and a procedure of purchasing real properties in connection with a landslide of 4 January 2011 (Dz.U. nr 5, poz. 14 [Journal of Laws No. 5, item 14]) (Dz.U. $2011 \mathrm{nr}$ 246, poz. 1468 as amended)
}

Pursuant to Art. 2 of the Act of 11 August 2011 on special principles of the reconstruction, renovation and demolition of structures destroyed or damaged as a result of the destructive influence of the element (Dz.U. No 84, item 906 and of 2010 No 149, item 996) it is ordered as follows:

$\$ 1$ The regulation specifies communes in which special principles of the reconstruction, renovation and demolition of structures destroyed or damaged as a result of the destructive influence of the element and special principles of land development as well as principles and a procedure of purchasing real properties in connection with a landslide shall be applied.

$\S 2$

5. The register of communes referred to in $\$ 1$, injured as a result of a flood, wind, intense precipitation or fires which took place in 2008, 2009 and 2010 and from January to 28 September 2011 constitutes appendix 1 to the regulation.

6. The register of communes referred to in $\$ 1$, injured as a result of a landslide specifies appendix 2 to the regulation.

$\S 3$ The provisions of the regulation shall be applied for the period of 24 months from the day it comes into force.

$\S 4$ The regulation comes into force on the day of its announcement.

Appendix 2. The register of communes injured as a result of a landslide

\begin{tabular}{|l|l|l|l|}
\hline LP. & WOJEWÓDZTWO & LP. & NAZWA GMINY \\
\hline 1 & 2 & 3 & 4 \\
\hline 1 & DOLNOŚLASKIE & 1 & ZAGRODNO \\
\hline 2 & LUBELSKIE & 1 & MILEJÓW \\
\hline 3 & MALOPOLSKIE & 1 & ALWERNIA \\
\cline { 2 - 4 } & & 2 & BIECZ \\
\cline { 2 - 4 } & & 3 & BISKUPICE \\
\cline { 2 - 4 } & & 4 & BOBOWA \\
\hline
\end{tabular}

Fig. 2. A fragment of the regulation of 4 January 2011 together with appendix 2 Source: Journal of Laws of 2011, No. 5, item 14 
Referring to the same communes several times in subsequent, simultaneously binding resolutions occurs occasionally. Thus, it will be more advisable and reliable to present the analyses carried out in a spatial and not quantitative manner.

The spatial analysis of communes selected in the binding resolutions as areas in which landslide-related disasters occurred has been presented below (Figs 3a, $4 a, 5 a, 6)$ as well as communes which actually took actions under special provisions consisting in enacting acts of local law in their own area (Figs $3 b, 4 b, 5 b$ ). Maps for each of the four analysed voivodeships have been presented.

a)

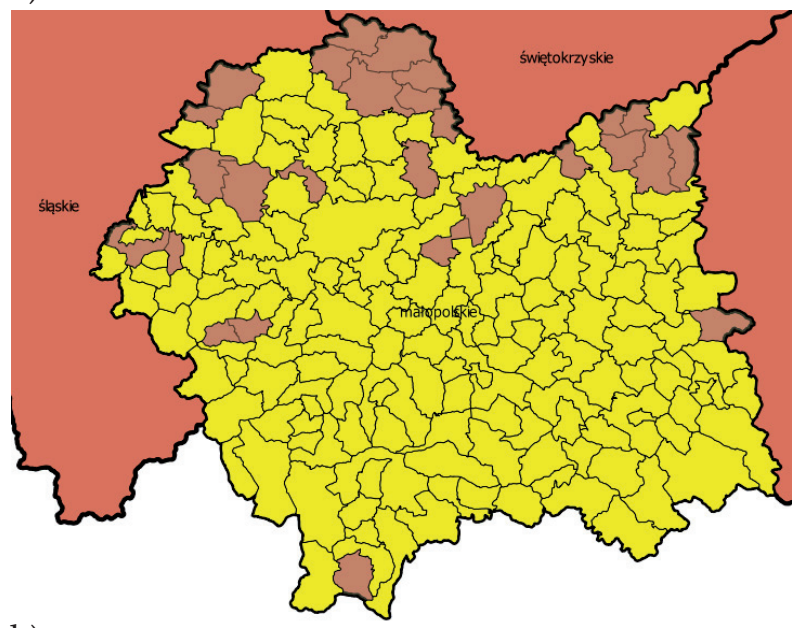

Communes named in the binding regulations of the Prime Minister

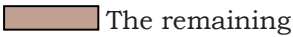
communes

b)

Communes which enacted acts of local law connected with the land development of the landslideaffected areas under special provisions

$\square$ The remaining communes

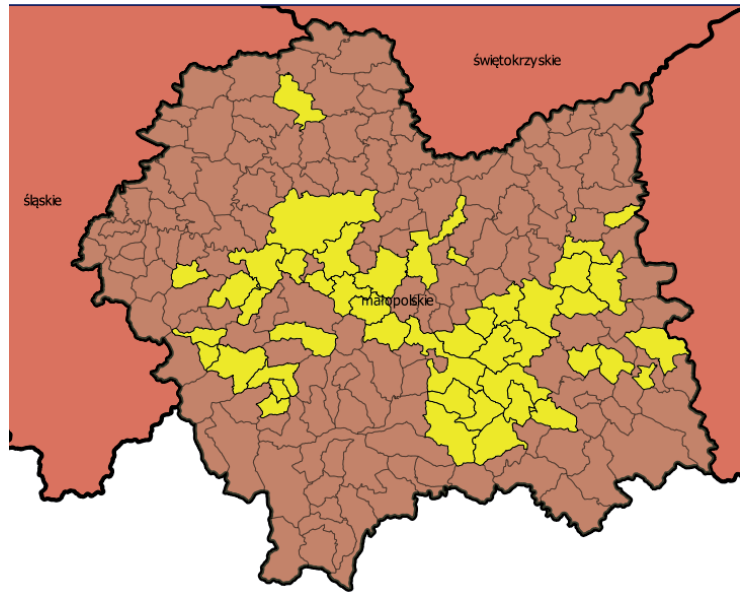

Fig. 3. The spatial distribution of the communes of Małopolskie Voivodeship named in the executive regulations to the Act [9] as areas in which landslide-related disasters occurred (a) and communes which passed resolutions connected with land development after these events in the form of local law acts (b) compared to all the communes of the voivodeship 

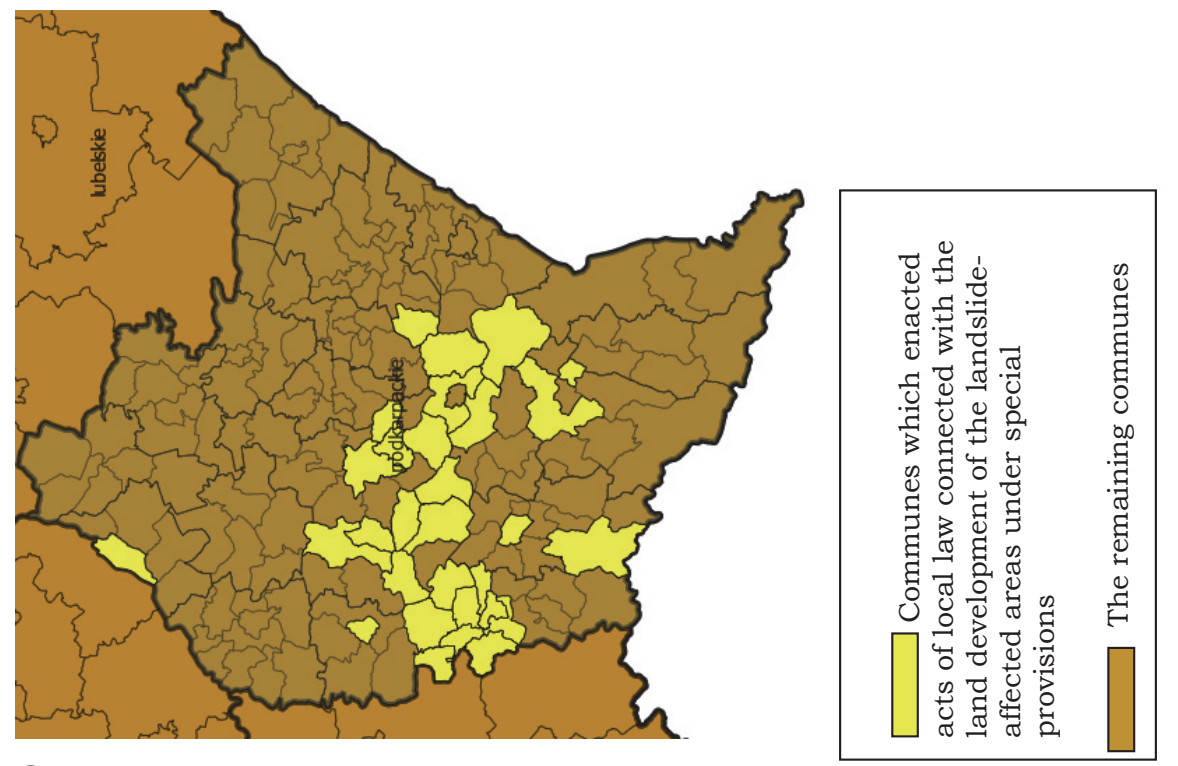

o
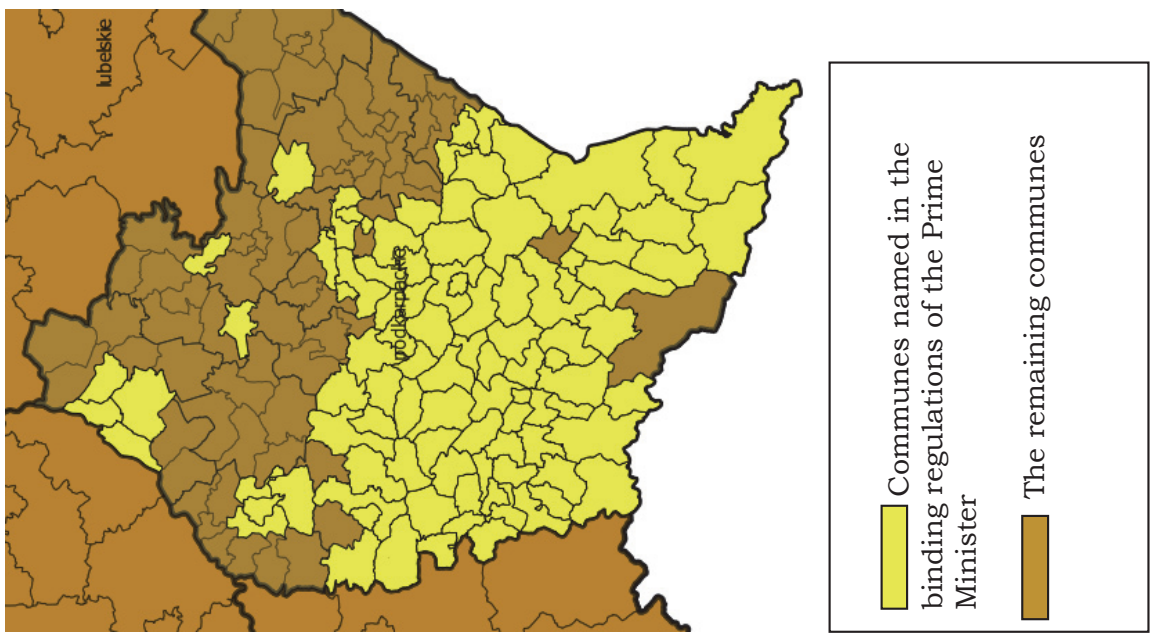

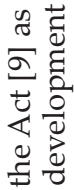

i $\bar{\Xi}$

.

중

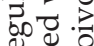

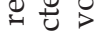

害焉

उ 잉

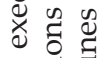

记。

$\leftrightarrows \Xi_{0}$

च 0

ฮृ

¿ี

을 옹

की च

ठ츄

. ते ڤ્

音

तु क्ष

윰

흉르

$0 త$

멍 등

岂

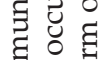

छี

8 范

๑

पृ

㐘

항

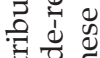

E.

च氙

. 크뉴

कै.

का.

ฮ

$F$

+ $\cong$

证 


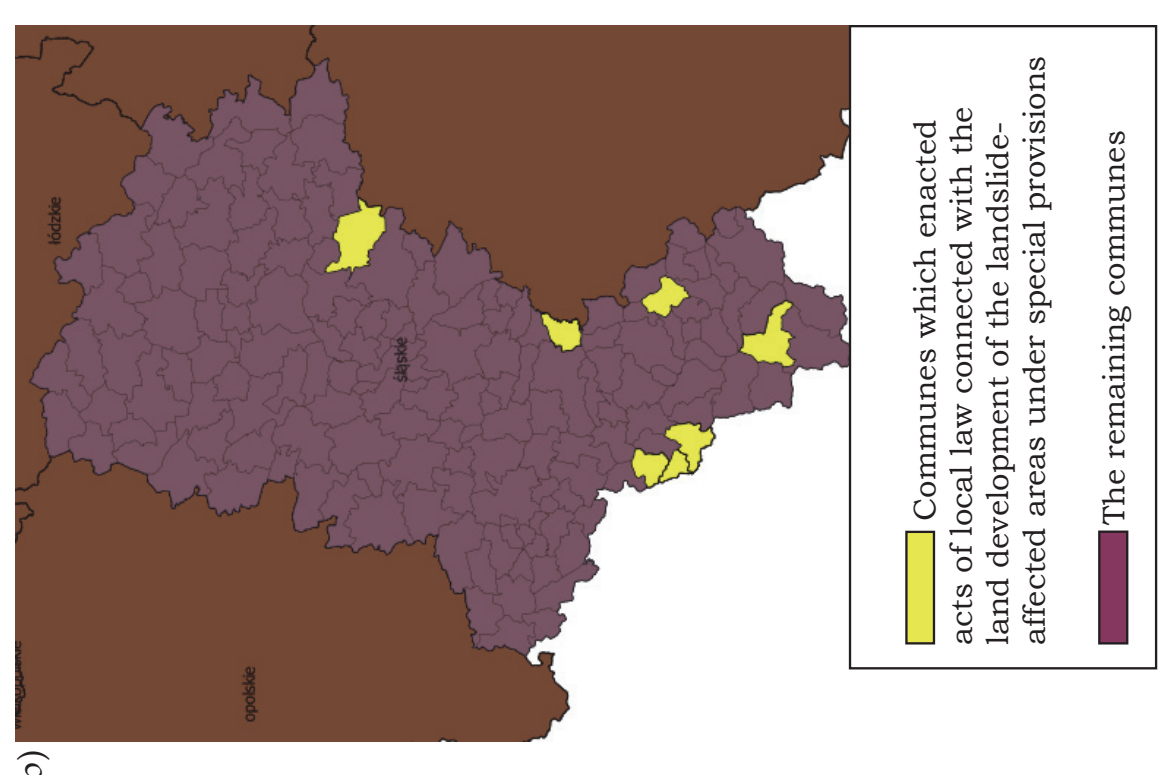

.

ปี

巳ั

ป

ब

¿

웅

工

용. 으

oै ?ำ

흥 용

독

0.03

ఫ

政㟧

己ृ

×

¿

Ð

ठृ

్ㅡ ซี

द

율

की

들 즈

근
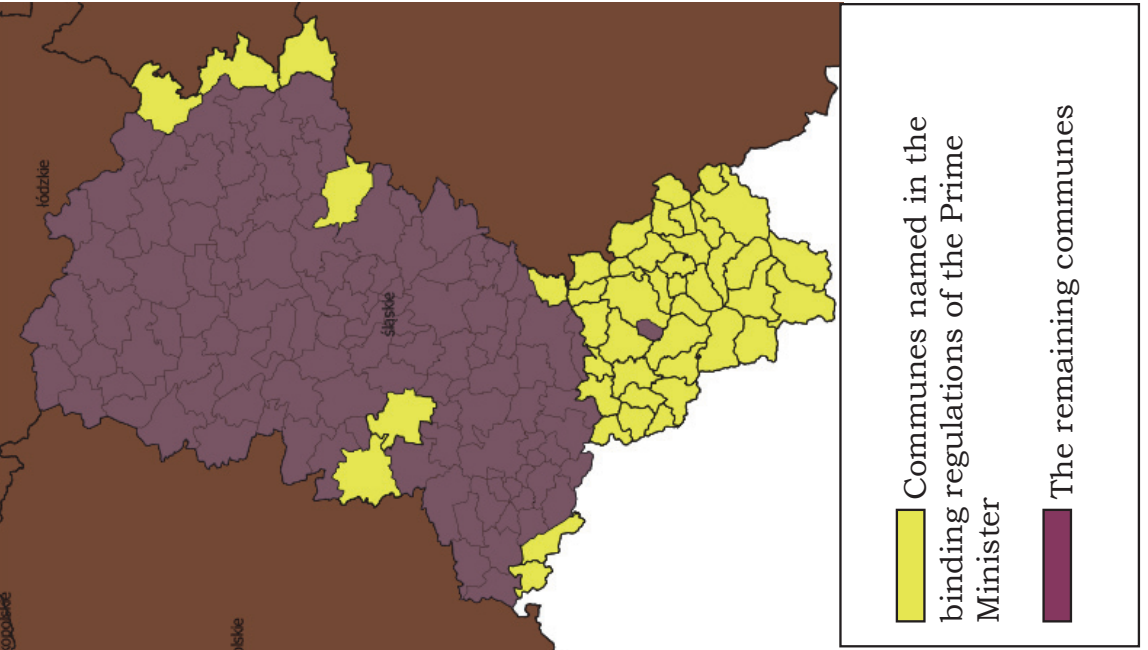

\&

\&

跣

芯

क ठ 3

을

\& 듬

ฮี ฮิ으

घㄷㅇㅇ

ठ્

ช

$\Xi$

पै की

.

萄

을

जo

.

휴

.ृ్ㄱ

क.

का ज

를

10.

我. 


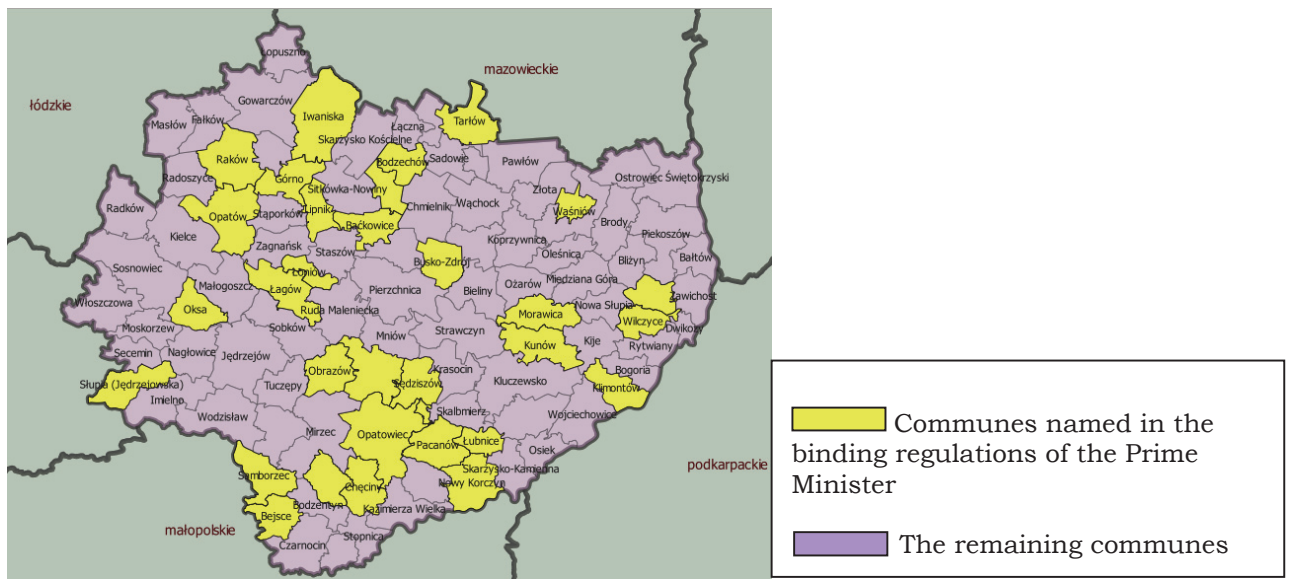

Fig. 6. The spatial distribution of the communes of Świętokrzyskie Voivodeship named in the executive regulations to the Act [9] as areas in which landslide-related disasters occurred compared to all the communes of the voivodeship

Comparing the number of communes named in the registers to the regulations to the total number of communes in a given voivodeship, the largest number, because as many as $85 \%$, was marked out as areas affected by disastrous landslides in Małopolskie Voivodeship and Podkarpackie Voivodeship (nearly 60\%). In Świętokrzyskie Voivodeship and Śląskie Voivodeship about 30\% of all the communes in the voivodeship were named in the regulations. Accurate numerical data is presented in Table 2.

Table 2. The qualitative analysis of communes named in executive regulations to the Act [9] as areas in which landslide-related disasters occurred and communes which enacted acts of local law connected with the land development of post-landslide areas under special provisions

\begin{tabular}{||l|c|c|c|c||}
\hline \multirow{2}{*}{ Characteristics } & \multicolumn{4}{c||}{ Voivodeship } \\
\cline { 2 - 6 } & Małopolskie & Podkarpackie & Śląskie & Świętokrzyskie \\
\hline $\begin{array}{l}\text { Total number of communes in the } \\
\text { voivodeship }\end{array}$ & 182 & 160 & 167 & 102 \\
\hline $\begin{array}{l}\text { Number of communes named in the } \\
\text { regulations of the Prime Minister }\end{array}$ & 155 & 92 & 46 & 31 \\
\hline $\begin{array}{l}\text { Number of communes named in the } \\
\text { regulations of the Prime Minister compared } \\
\text { to total number of communes in the } \\
\text { voivodeship [\%] }\end{array}$ & 85 & 58 & 28 & 30 \\
\hline $\begin{array}{l}\text { Number of communes in which resolutions } \\
\text { were passed in connection with mapping out } \\
\text { post-lanslide areas }\end{array}$ & 42 & 28 & 7 & 0 \\
\hline $\begin{array}{l}\text { Number of communes in which resolutions } \\
\text { were passed in connection with mapping out } \\
\text { post-lanslide areas compared to number of } \\
\text { communes named in the regulations [\%] }\end{array}$ & 27 & 30 & 15 & 0 \\
\hline
\end{tabular}


In Małopolskie Voivodeship actions under special provisions through adopting resolutions by the commune/city council on appointing areas in connection with landslide movements were taken $27 \%$ of all the communes in the voivodeship. The resolutions concerned appointing all the three types of areas, both areas under construction prohibition, those in which a landslide has occurred and those in which local reconstruction plans were enacted. In total, 82 resolutions were passed and its percentage distribution depending on the type of an area which they concerned is presented in the pie chart below (Fig. 7).

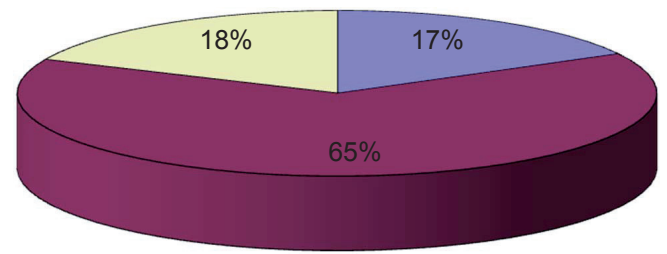

口Local reconstruction plan

口Damage-affected area

$\square$ Areas under building prohibition

Fig. 7. Percentage distribution of the announced resolutions of the coommune councils of Małopolskie Voivodeship concerning the determination of three types of areas in connection with landslide movements occurrence

A similar level of activity with respect to the passing local acts was observed in Podkarpackie Voivodeship. Out of 92 marked out communes about 30\% took action in order to change land use classification. This action focused only on determining an area in which landslide related damage has occurred. 29 acts of local law within 28 communes were enacted. In Śląskie Voivodeship areas affected by landslides were mapped out in 7 communes and the total number of all the marked out communes amounted to 49 .

No resolutions of commune councils concerning landslide areas were found for Świętokrzyskie Voivodeship, although there were 31 communes which suffered damage as a result of the destructive influence of the element, among other things landslides, marked out by the resolution.

\section{Conclusions}

This article was aimed at examining if and to what extent communes from the areas of Poland affected by landslide-related disasters after 2010 take advantage of the possibility given to them by the amended Act on special principles of the reconstruction, renovation and demolition of structures destroyed or damaged as a result of the destructive influence of the element [6]. The research revealed that during the period considered the largest proportion of communes named in the registers to the regulations of the prime minister as those which suffered damage 
as a result of the destructive influence of the element, among other things, landslides, compared to the total number of communes in a given voivodeship was in Małopolskie Voivodeship (85\%). In this voivodeship communes took advantage of the possibilities created by the amended Act with respect to the change in land use classification in connection with landslides occurrence most actively. It is evidenced by a considerable amount of resolutions concerning action with respect to determining areas in which landslide-related construction disasters took place. Moreover, local reconstruction plans were enacted in Lanckorona commune, areas under building prohibition were mapped out due to the risk of landslides, among other things, in Skawina commune, in the city of Krakow, in Bochnia. In Podkarpackie and Śląskie Voivodeships communes took resolution-passing action as a result of which areas where landslide-related damage occurred were mapped out. There were no communes which announced local reconstruction plans or prohibited building under analysed special provisions in these voivodeships. The communes of Świętokrzyskie Voivodeship did not take resolution-passing action although $30 \%$ of communes from this voivodeship were referred to in executive acts to the Act [9].

To sum up, the research revealed the activeness of communes in taking advantage of the possibilities created by legislative changes with respect to special provisions concerning post-landslide damage. An increase in the awareness of threats caused by landslide movements among administration representatives can be seen. Few examples of applying special provisions in order to enact local reconstruction plans and to map out areas under building prohibition were observed (only in Małopolskie Voivodeship). It is certainly connected with a financial aspect and the necessity of disposing funds, eg. for real property buyout, paying compensation, infrastructure building in areas to which local reconstruction plans apply. First of all, however, low social awareness concerning threats in landslide areas, reluctance to change the place of residence, little confidence in commune authorities and certain procedures, eg.land expropriation, may be a problem. It can be seen very often that land owners treat property right in land and the possibility of land development as one to such an extent that even real threats to life or health are ignored.

Regardless of the above conclusions the publication was conceived by the author as a step towards disseminating knowledge of special legal regulations concerning areas affected or threatened by landslide movements, particularly with respect to land use classification, the reconstruction of existing and damaged structures (also in other places not threatened by another landslide), as well as specifying the principles and conditions on which the reconstruction of buildings in the former place would ensure their users' safety. The author hopes that the research will contribute to increasing the awareness of administration representatives in respect of the examined subject matter as well as to more frequent and eager employment of the already tested and effective procedures in order to come to the aid of landslide disaster victims. 


\section{References}

[1] Bieda A., Hanus P., Hycner R.: Geodezyjne aspekty planowania przestrzennego i wybranych opracowań projektowych. Wydawnictwo Gall, Katowice 2012.

[2] Kwartnik-Pruc A., Szafarczyk A.: Designating agricultural land for investment purposes and the requirements of environmental sustainability. Polish Journal of Environmental Studies, vol. 20, no. 4A, 2011, pp. 212-216.

[3] Ministry of Environment: Działania resortu środowiska w zakresie systemu osłony przeciwosuwiskowej w Polsce. Warszawa 2010, [on-line:]

www.mos.gov.pl/oslona_przeciwosuwiskowa [access: 10 November 2014].

[4] Szafarczyk A., Kwartnik-Pruc A.: Issues regarding taking landslide areas into account in spatial planning in Poland. [in:] FIG Working Week 2012: Knowing to manage the territory, protect the environment, evaluate the cultural heritage: Rome, Italy, 6-10 May, [on-line:]

http://www.fig.net/pub/fig2012/papers/ts071/TS07L_szafarczyk_kwartnikpruc_5697.pdf [access: 10.11.2014].

[5] Ustawa z dnia 27 kwietnia 2001 r. - Prawo ochrony środowiska. Dz.U. $2001 \mathrm{nr}$ 62, poz. 627.

[6] Ustawa z dnia 11 sierpnia 2001 r. o szczególnych zasadach odbudowy, remontów i rozbiórek obiektów budowlanych zniszczonych lub uszkodzonych w wyniku działania żywiołu. Dz.U. nr 84, poz. 906.

[7] Ustawa z dnia 18 kwietnia 2002 r. o stanie klęski żywiołowej. Dz.U. 2002 nr 62, poz. 558.

[8] Ustawa z dnia 27 marca 2003 r. o planowaniu i zagospodarowaniu przestrzennym. Dz.U. 2003 nr 80, poz. 177.

[9] Ustawa z dnia 6 sierpnia 2010 r. o zmianie ustawy o szczególnych zasadach odbudowy, remontów i rozbiórek obiektów budowlanych zniszczonych lub uszkodzonych w wyniku działania żywiołu oraz niektórych innych ustaw. Dz.U. 2010 nr 149, poz. 996. 